\title{
The influence of multifetal pregnancy embrioreduction in high-risk pregnancies - clinical management and outcome
}

\section{Uticaj multifetalne embrioredukcije kod visokorizičnih trudnoća - klinički pristup $i$ ishod}

Petar Zlatanović ${ }^{1}$, Stefan Zaharijev ${ }^{1}$, Željko Mikovićc ${ }^{1,2}$

\author{
${ }^{1}$ Medicinski fakultet Univerziteta u Beogradu \\ ${ }^{2}$ Mentor: Odeljenje za visokorizične trudnoće, GAK „Narodni front“
}

Kontakt: petarzlatanović@yahoo.com

Abstract

Introduction: To decrease the risks associated with triplets pregnancies MFPR is preformed. The most frequently applied method is through ultrasound guided transabdominal injection of potassium chloride into the fetal heart or chest cavity at 11-14 weeks of gestation.

Aim: The main objective of this study was to evaluate perinatal outcomes in triplet pregnancies after transabdominal MFPR as compared with ongoing triplet pregnancies and twin pregnancies.

Material and methods: In this retrospective study, all women with trichorionic triplet pregnancies undergoing MFPR to a twin pregnancy, women with an ongoing trichorionic triplet pregnancy and with those with a primary dichorionic twin pregnancy were included.

Results: Median gestation age at delivery was 35.6 ( interquartile range [IQR], 32.8-37 weeks) for triplets reduced to twins, 32.8 weeks (IQR, 27.6-34.7 weeks) for ongoing triplets, and 37 weeks ( IQR, 35.1-38.3 weeks) for primary twins ( $\mathrm{p}<0.01$ difference between all groups). There were 7 women in the reduction group (12.28\%) vs $10(19.6 \%)$ in the ongoing triplet group, whi and 4 (6.66\%) in the primary twin group in whom not a single fetus survived. Preterm delivery before 32 weeks of gestation occurred less in the reduction group compared with the ongoing triplets (12 [20.9\%] vs 18 [35.29\%] ), but still more often than in primary twins - 7 (11.66\%).

Conclusion: Multifetal pregnancy reduction (MFPR) seems to be associated with a decreased risk of pregnancy loss both before 24 and 32 weeks of gestation in women with trichorionic triplet reduction.

Key words: MFPR, multiple pregnancy, early reduction, pregnancy outcome, triplets

\section{Introduction}

Over the past three decades the incidence of triplets and high-order pregnancy has increased from 37 per

\section{Sažetak}

Uvod: Multifetalna embrioredukcija (engl. Multifetal pregnancy reduction, MFPR) se primenjuje kao jedna od metoda za smanjenje rizika kod trudnoća sa tri ploda. Najčešća primenjivana metoda MFTR je ultrazvukom vođena intrakardijalna ili intratoraklna primena kalijum hlorida između 11 i 14 nedelje gestacije.

Cilj: Osnovni cilj ove studije je da proceni uticaj transabdominalne $M F P R$ kod trudnoća sa tri ploda u poređenju sa trudnoćama sa tri ploda bez MFPR i blizanačkih trudnoća.

Materijal i metode: $U$ ovoj retrospektivnoj studiji uključene su sve žene sa trihorionskim tripletima kojima je rađen $M F P R$, žene sa tekućim trihorionskim trudnoćama i blizanačkim trudnoćama.

Rezultati: Srednja gestacijska starost bila je 35,6 nedelja za triplete redukovane uz pomoć MFPR do blizanačkih trudnoća (interkvartalni opseg $[I Q R], 32,8-37$ nedelja), 32,8 nedelja ( $I Q R, 27,6-34,7$ nedelja) za tekuće horionske triplete i 37 nedelja (IQR, 35,1-38,3 nedelja) za blizanačke trudnoće ( $\mathrm{p}<0,01$, statistički značajna razlika između grupa). Kompletan gubitak trudnoće pre 24 nedelje se desio kod 7 trudnoće nakon redukcije (12.28\%) vs 10 tripleta bez redukcije (19,6\%) i 4 kod primarnih blizanaćkih trudnoća (6,66\%). Prevremeni porođaj pre 32 nedelje gestacije se desio u manjem broju kod MFTR grupe u poređenju sa grupom bez redukcije (12 [20,9\%] vs 18 [35,29\%] ), ali i dalje više kod primarnih blizanačkih trudnoća - 7 (11,66\%).

Zaključak: Multifetalna embrioredukcija je povezana sa manjim rizikom od gubitka trudnoće pre 24 i 32 nedelje gestacije kod žena sa trihorionskim tripletima.

Ključne reči: $M F P R$, tripleti, multiple trudnoće, ishod trudnoće, rana redukcija

100000 in 1980 to 153 per 100000 births in the United States, mainly because of use of assisted reproductive technology (ART) (1). Methods of ART that contribute the most to multifetal pregnancies are in vitro fertilisation (IVF) and controlled ovarian stimulation (COS). Ac- 
cording to the data $43 \%$ of triplets and high-order pregnancies is a result from IVF, $39 \%$ is a consequence form COS and $18 \%$ of them occurs spontaneously (2). The risk of perinatal mortality and morbidity rises with the number of fetuses. Triplet pregnancies are at an increased risk of neonatal morbidity and mortality compared with twin or singleton pregnancy, mainly because of increased risk of preterm birth (3). The risk of spontaneous abortion is $15 \%$ for triplets and $8 \%$ for twins (4). Compared with women with twin gestation, those with triplets have a significantly increased risk of maternal morbidity such as gestational diabetes mellitus (GDM), hypertensive disorders such as preeclampsia and cesarean delivery (5).

To decrease the risks associated with triplets and high-order pregnancies multifetal pregnancy reduction (MFPR) is performed and several approaches have been described. The most frequently applied method is through ultrasound guided transabdominal injection of potassium chloride into the fetal heart or chest cavity at 11-14 weeks of gestation (6,7). Several advantages are associated with MFPR at 11-14 weeks, including the opportunity to carry out chorionic villus sampling, non-invasive prenatal testing, ultrasound screening for anomalies etc. However, in the event of triplet pregnancy, there remains dabate whether multifetal pregnancy reduction improves obstetrics outcome of triplets reduced to twins.

Thus, the main objective of this study was to evaluate the effectiveness of early transabdominal MFPR as compared with ongoing triplet pregnancies and twin pregnancies in terms of perinatal outcomes.

\section{Materials and methods}

In this retrospective study, all women with triplet pregnancies undergoing fetal reduction to a twin pregnancy at the Clinic for Gynecology and Obstetrics "Narodni Front" over the period of 2009-2014 were included. The procedure was performed transabdominally after local anesthetic by using $20 \mathrm{G}$ or $22 \mathrm{G}$ needle and injecting potassium chloride intracardially. All procedures were performed between 11 and 14 weeks of gestation. Women were identified by searching in the ultrasound, obstetrics and fetal databases at the unit of high-risk pregnancies at the Clinic for Gynecology and Obstetrics "Narodni Front", where MFPR was preformed. The cases in which fetal reduction was preformed because of congenital anomaly fetus were not included in the study. The study was limited to trichorionic triplets only. Chorionicity was determined at the first-trimester ultrasound scan.

The course of pregnancy in women with a reduced triplet was compared with the outcome in women with an ongoing triplet pregnancy and with those with a primary dichorionic twin pregnancy. All trichorionic triplet pregnancies in the period of 2009-2014 with at least 1 ultra- sound performed between 8 and 15 weeks of gestation in which 3 living fetuses were identified and fetal reduction was not performed were included in the control group of ongoing triplet pregnancies. Data regarding original dichorionic twin pregnancies were collected using a similar selection procedure as described for the triplet control group, but was limited to women with 2 living fetuses.

Data were collected retrospectively by reviewing maternal and where appropriate neonatal medical records. Maternal and fetal characteristics, including demographic data ultrasound findings, fetal measurements, chorionicity, and pregnancy outcome were collected. The rates of pregnancy complications, including gestational diabetes, gestational hypertension, intrauterine growth restriction, placental abruption, premature rupture of membrane and delivery mode were determined and compared. The outcome of the 3 groups (triplets reduced to twins, ongoing triplets, and primary twins) was compared in terms of gestational age at delivery, delivery less than 24 weeks, delivery less than 32 weeks, neonatal birth weight. For perinatal mortality women who had all their children or no children surviving were compared.

Normality of the data was tested using ShapiroWilk or Kolmogorov-Smirnov tests. Comparison of continuous variables between the two groups was conducted using Mann-Whitney $\mathrm{U}$ test or student t-test as appropriate and between three groups 1-way analysis of variance (ANOVA) test or Kruskal-Wallis test when the data were not normally distributed. Chi-squared or Fisher's exact test was used for comparison of categorical variables. Significance was set at $\mathrm{P}<0.05$. All statistical analysis were performed using SPSS 20 (SPSS Inc, Chicago, IL).

\section{Results}

Fifty seven women with a trichorionic triplet pregnancy who underwent fetal reduction to a twin pregnancy were identified. The mean gestational age at reduction was $12.2 \pm 0.9$ weeks. Fifty one women with trichorionic triplet pregnancies without reduction and 60 women with dichorionic twin pregnancy were identified as a control group. The baseline characteristics of the 3 groups are shown in table 1.

table 1. Baseline characteristics in three groups (triplet pregnancy who underwent fetal reduction to a twin pregnancy vs triplet pregnancies without reduction vs dichorionic twin pregnancy).

\begin{tabular}{lcccc}
\multicolumn{5}{c}{ Baseline characteristics } \\
Characteristics & $\begin{array}{c}\text { Reduction } \\
(\mathbf{n}=\mathbf{5 7})\end{array}$ & $\begin{array}{c}\text { Triplet } \\
(\mathbf{n}=\mathbf{5 1})\end{array}$ & $\begin{array}{c}\text { Twin } \\
(\mathbf{n}=\mathbf{6 0})\end{array}$ & P value \\
\hline Maternal age & $31.02(4.32)$ & $30.98(4.58)$ & $30.33(5.15)$ & 0.599 \\
\hline Nulliparous & $32(56.14)$ & $17(33.33)$ & $30(50)$ & 0.04 \\
\hline Spontaneous conception & $7(11.66)$ & $20(39.21)$ & $37(61.66)$ & $<0.01$ \\
\hline \multicolumn{4}{c}{ Data are presented as mean (SD) or number (percentage) } \\
\hline
\end{tabular}


Regarding complications, there wasn't discovered any statistically significant difference among three groups regarding gestational hypertension, gestational diabetes, placental abruption, intrauterine growth restriction and premature rupture of membrane (table 2).

table 2. Perinatal complications among three groups (triplet pregnancy who underwent fetal reduction to a twin pregnancy vs triplet pregnancies without reduction vs dichorionic twin pregnancy)

\begin{tabular}{lllll}
\hline \multicolumn{5}{c}{ Perinatal complications } \\
Complications & $\begin{array}{c}\text { Reduction } \\
(\mathbf{n}=\mathbf{5 7})\end{array}$ & $\begin{array}{c}\text { Triplet } \\
(\mathbf{n}=\mathbf{5 1})\end{array}$ & $\begin{array}{c}\text { Twin } \\
(\mathbf{n}=\mathbf{6 0})\end{array}$ & P value \\
\hline Gestational hypertension & $11(19.29)$ & $17(29.82)$ & $15(25)$ & 0.356 \\
\hline Gestational diabetes & $3(5.26)$ & $6(11.76)$ & $5(8.33)$ & 0.54 \\
\hline Placental abruption & $2(3,55)$ & $6(11.76)$ & $3(5)$ & 0.241 \\
\hline Intrauterine growth restriction & $9(15.78)$ & $12(23.53)$ & $11(18.33)$ & 0.68 \\
\hline Premature rupture of membrane & $12(21.05)$ & $13(25,49)$ & $15(16.66)$ & 0.627 \\
\hline \multicolumn{5}{c}{ Data are presented as number (percentages) } \\
\end{tabular}

No significant difference was found between three groups in terms of mode of delivery (table 3 ).

table 3. Delivery mode among three groups (triplet pregnancy who underwent fetal reduction to a twin pregnancy vs triplet pregnancies without reduction vs dichorionic twin pregnancy)

\section{Delivery mode}

\begin{tabular}{lcccc} 
Mode & $\begin{array}{c}\text { Reduction } \\
(\mathbf{n}=\mathbf{5 7})\end{array}$ & $\begin{array}{c}\text { Triplet } \\
(\mathbf{n}=\mathbf{5 1})\end{array}$ & $\begin{array}{c}\text { Twin } \\
(\mathbf{n}=\mathbf{6 0})\end{array}$ & P value \\
\hline Vaginal delivery & $11(22)$ & $7(17.07)$ & $12(20)$ & 0.165 \\
\hline Cesarean delivery & $39(78)$ & $34(82.92)$ & $48(80)$ & 0.229 \\
\hline \multicolumn{5}{c}{ Data are presented as number (percentages) } \\
\hline \multicolumn{5}{c}{}
\end{tabular}

Median gestation age at delivery was 35.6 ( interquartile range [IQR], 32.8-37 weeks) for triplets reduced to twins, 32.8 weeks (IQR, 27.6-34.7 weeks) for ongoing triplets, and 37 weeks ( IQR, 35.1-38.3 weeks) for primary twins ( $\mathrm{p}<0.01$ difference between all groups) (Table 2). Loss of the complete pregnancy prior to 24 weeks occured in 3 pregnancies after reduction (5.3\%) vs in 9 ongoing triplets (19.6\%) and 2 primary twins (3.33\%). Preterm delivery before 32 weeks of gestation occurred less common in the reduction group compared with the ongoing triplets ( 12 [20.9\%] vs 18 [35.29\%] ), but still more often than in primary twins 7 (11.66\%). The mean neonatal birthweight was $2230.83 \pm 533.94$ in the reduction group, $1613.05 \pm 428.893$ in the ongoing triplets and $2336.4 \pm 587.98$ in primary twins $(\mathrm{p}<0.01$, difference between all groups) (table 4). table 4. Pregnancy outcomes by group (triplet pregnancy who underwent fetal reduction to a twin pregnancy vs triplet pregnancies without reduction vs dichorionic twin pregnancy)

\begin{tabular}{|c|c|c|c|c|}
\hline \multicolumn{5}{|c|}{ Pregnancy outcome by group } \\
\hline Variable & $\begin{array}{l}\text { Reduction } \\
(\mathrm{n}=\mathbf{5 7})\end{array}$ & $\begin{array}{l}\text { Triplet } \\
(\mathrm{n}=51)\end{array}$ & $\begin{array}{c}\text { Twin } \\
(n=60)\end{array}$ & Pvalue \\
\hline $\begin{array}{l}\text { Gestational age } \\
\text { ate delivery, weeks }\end{array}$ & $35.6(32.8-37)$ & $32.8(27.6-34.7)$ & $37(35.1-38.3)$ & $<0.01$ \\
\hline Delivery $<24$ wweks & $3(5.3)$ & $9(19.6)$ & $2(3.33)$ & 0.03 \\
\hline Delivery $<32$ weeks & $12(21.05)$ & $18(35.29)$ & $7(11.66)$ & $<0.01$ \\
\hline Mean birth weight, grams & $2230.83(533.94)$ & $1613.05(428.893)$ & $2336.4(587.98)$ & $<0.01$ \\
\hline
\end{tabular}

The total number of surviving children in the reduced group was 98 of $114(85.96 \%)$ vs 123 of 153 $(77.12 \%)$ in the ongoing triplet group and 110 of 120 (91.66\%) for primary twins. This difference was statistically significant $(f=105.512, p<0.01)$. When compared, the difference between reduction and triplet group was statistically significant $\left(\chi^{2}=5,231, p=0.022\right)$, but this difference wasn't significant between reduction and twin group $\left(\chi^{2}=3.122, \mathrm{p}=0.125\right)$.

The number of women who had all their fetuses surviving that were intended to survive was 50 of 54 $(87.71 \%)$ in the reduction group vs 41 of $51(80.39 \%)$ for ongoing triplets and 56 of $60(93.33 \%)$ for primary twins $(\mathrm{p}<0.04)$. There were 7 women in the reduction group $(12.28 \%)$ vs $10(19.6 \%)$ in the ongoing triplet group, whi and $4(6.66 \%)$ in the primary twin group in whom not a single fetus survived (table 5).

table 5. Perinatal mortality among three groups (triplet pregnancy who underwent fetal reduction to a twin pregnancy vs triplet pregnancies without reduction vs dichorionic twin pregnancy)

\begin{tabular}{lcccc}
\multicolumn{5}{c}{ Perinatal mortality } \\
Variable & $\begin{array}{l}\text { Reduction } \\
(\mathbf{n = 5 7 )}\end{array}$ & $\begin{array}{c}\text { Triplet } \\
(\mathbf{n}=\mathbf{5 1})\end{array}$ & $\begin{array}{c}\text { Twin } \\
(\mathbf{n}=\mathbf{6 0})\end{array}$ & P value \\
\hline All women with surviving fetuses & $50(87.71)$ & $41(80.39)$ & $56(93.33)$ & 0.004 \\
\hline Women without surviving fetuses & $7(12.28)$ & $10(19.6)$ & $4(6.66)$ & 0.03 \\
\hline \multicolumn{7}{c}{ Data are presented as number (percentages) } \\
\end{tabular}

\section{Discussion}

This study showed the effectiveness of the reduction of 1 fetus in a trichorionic triplet pregnancy. Reduction resulted in more advanced gestation at birth as compared with expectant management in triplets, 35.6 vs 
32.8 weeks of gestation, although primary twins still did slightly better.

The baseline characteristics of the 3 groups differed for mode of conception and parity, because of the fact that this was not a randomised controlled trial. This study is partially in concordance with previous published studies, because it also showed an improvement in the median gestational age from 33 to 36 weeks (8-10). However when compared with research from Papageorghiou et al., it showed a lower risk of pregnancy loss prior to 24 weeks from triplets to twins (5.3 vs $8.2 \%$ in the review of Papageorghiou et al.) and a higher risk of pregnancy loss prior to 24 weeks in ongoing triplet pregnancies (19.46\% vs $4.3 \%$ ) (11). A possible explanation for this difference could be that inclusions started to early. Women who had, for example, 3 living fetuses at 12 weeks gestation and a miscarriage at 14 weeks gestation.

In contrast, Evans and Britt reported a decrease in the pregnancy loss rate after MFPR in triplet pregnancy from $15 \%$ to $5 \%$, with triplets reduced to twins doing almost as well as nonreduced twins (12). Apparently the procedure of MFPR itself can cause pregnancy loss prior to 24 weeks gestation, and this possible risk should be specifically mentioned when counseling parents opting for MFPR. Because the interval between the reduction and the miscarriage was usually more than 2 weeks, it is also important to stress that most of the excess loss may occur several weeks after the procedure.

Moreover, sample size was limited, only 51 cases with triplets and 60 with twins met inclusion criteria for control group, which is a small number. This small number could have influenced the data. The data also showed a reduction in the delivery rate less than 32 weeks from $35.29 \%$ to $21.05 \%$ which is comparable with Papageorghiou et al. who found a reduction from $28.8 \%$ to $18 \%$. Unfortunately, this study didn't show neonatal morbidity, due to lack of reliable data in our control groups. As surrogate the gestational age was used. Gestational age at birth is a good proxy for neonatal morbidity. Apparently the increased gestational age among reduced triplets will have reduced short-term morbidity and mortality. Unfortunately, the long-term outcome of these children was not studied.

In terms of pregnancy complications and delivery mode there wasn't found any difference. These results could be explained by the relatively small number of patients, which might restrict the ability to detect differences. Therefore, a large prospective study is needed to validate the results.

In summary, MFPR seems to be associated with an decreased risk of pregnancy loss both before 24 nad 32 weeks of gestation in women with trichorionic triplet re- duction. This in significant reduction in perinatal deaths. Nevertheless, the prevention of multiple gestations therefore should have priority over MFPR. However, when these pregnancies occur despite adequate precautions, parents should be counseled for MFPR.

\section{References}

1. Martin JA, Hamilton BE, Ventura SJ, JK Osterman, TJ Mathews, Katy B. Kozhimannil et al. Births: final data for 2011. Natl Vital Stat Rep 2013;62:1-72.

2. Pons JC, Charlemaine C, Dubreuil E, Papiernik E, Frydman R. Management and outcome of triplet pregnancy. Eur J Obstet Gynecol Reprod Biol 1998;76:131-9.

3. Strauss A, Paek BW, Genzel-Boroviczény O, Schulze A, Janssen U, Hepp H. Multifetal gestation-maternal and perinatal outcome of 112 pregnancies. Fetal Diagn Ther 2002;17: 209-17.

4. 4. Sebire NJ, D'Ercole C, Sepulveda W, Hughes K, Nicolaides KH. Effects of embryo reduction from trichorionic triplets to twins. Br J Obstet Gynaecol 1997;104:1201-3.

5. Luke B, Brown MB. Maternal morbidity and infant death in twin vs triplet and quadruplet pregnancies. Am J Obstet Gynecol 2008;198: 401.e1-10.

6. Mansour RT, Aboulghar MA, Serour GI, Sattar MA, Kamal A, Amin YM. Multifetal pregnancy reduction: modification of the technique and analysis of the outcome. Fertil Steril 1999;71:380-4.

7. Lipitz S, Shulman A, Achiron R, Zalel Y, Seidman DS. A comparative study of multifetal pregnancy reduction from triplets to twins in the first versus early second trimesters after detailed fetal screening. Ultrasound Obstet Gynecol 2001;18:35-8.

8. Evans MI, Britt DW. Fetal reduction 2008. Curr Opnin Obstet Gynecol 2008:386-93.

9. Dodd JM, Crowther CA. Reduction of the number of fetuses for women with multiple pregnancies. Cochrane Database Syst Rev 2012;10:CD003932.

10. Spencer JV, Ingardia CJ, Nold CJ, Borgida AF, Herson VC, Egan JF. Perinatal and neonatal outcome of triplet gestations based on placental chorionicity. Am J Perinatol 2009;26: 587-90.

11. Papageorghiou AT, Avigidou KA, Bakoulas V, Sebire NJ, Nicolaides KH. Risk of miscarriage and early preterm birth in trichorionic triplet pregnancies with embryo reduction versus expectant management: new data and systematic review. Hum Reprod 2006;21:1912-7.

12. Evans MI, Britt DW. Fetal reduction 2008. Curr Opnin Obstet Gynecol 2008:386-93. 